\title{
EDTA 法による鉊快削鋼中の鉛の定量
}

(鉛快削鋼の研究一V)

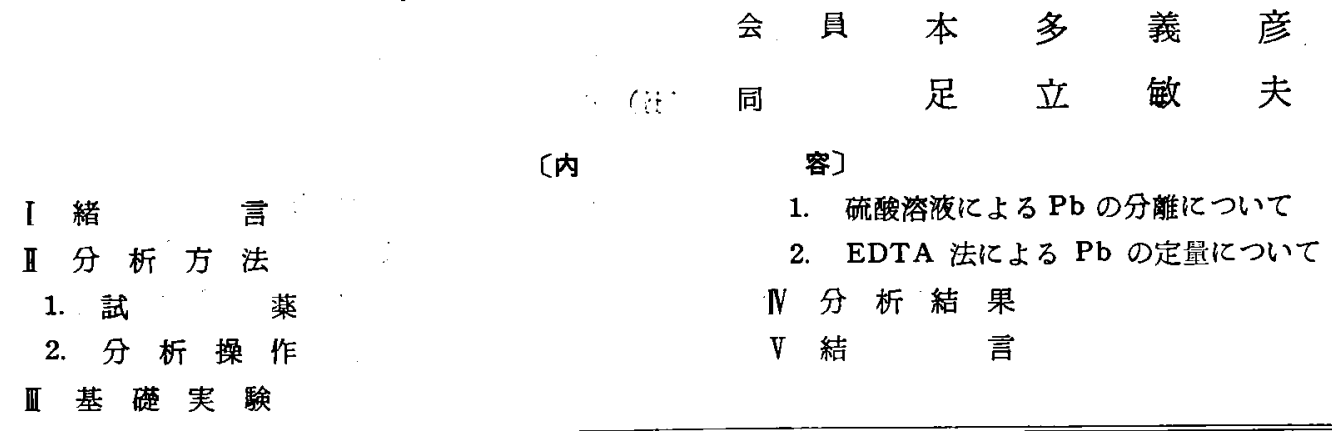

\section{I 緒言}

炭素鋼，低合金鋼汇鉛を $0.150 \% \sim 0.35 \%$ 添加 した所謂鉛快削鋼が近時自動車用鋼等に広く利 用され始めた．銛は鉄と固浴体をつくらず金属 鉛, 硫化鉛等の微粒子となって鋼中に存在する といわれている。そのため鋼塊内，鋼塊間の鉛 の分布状態は同一とならず若干のバラッキは避 けられない現状である．当社では鋼材管理上各 鋼塊でとに top.と bottom の2 2 ケ所で試料を採 取し発汗試験，分析結果等より鋼材の均一性を 検查している。このため分析件数は多数となり 分析処理能率の増進が問題となってきた，
鋼中の鉛分析法として従来多くの方法が紹介 されている．すなわちスペクトログラフ法，X 線回折法，螢光X線分析法ととも亿化学的操作 を必要とするポーラログラフ法2)，比斶法3)，比 色法(4) (6)，重量法8)，7)等がある。分析精度が若 干落ちるスペクトログラフ法, 新化設備を必要 とするX線法*を除外して分析方法を種々検討 し, 硫酸分離 EDTA容量法を確立し日常分析 法として満足な結果を得た。乙れら正確度が比 較的良好な諸方法について特徵を比較したのが 第1表である。

とれらの方法を分析操作より大別すると，鉛 を多くの鉄から分離するか或はしないか，また

第 1 表分析法

\begin{tabular}{|c|c|c|c|c|c|c|}
\hline \multirow{2}{*}{ 項目 $1^{\text {分 }}$ 析 } & \multirow{2}{*}{$\begin{array}{l}\text { ホララロ } \\
\text { グラフ法 }\end{array}$} & \multicolumn{2}{|c|}{ 比色 法 } & \multicolumn{2}{|c|}{ 重 量 } & \multirow{2}{*}{ EDTA 法 } \\
\hline & & シチゾン & 沃 & $\begin{array}{l}\text { 硫化水素 } \\
\text { 分 離 }\end{array}$ & 硫酸分䨆 & \\
\hline 度 & 良 & 良 & 稍々不良 & 良 & 良 & 良 \\
\hline 確 & 良 & 良 & 良 & 良 & 良 & 良 \\
\hline 練 & 不 要 & 要 & 要 & 稍々要 & 不 & 不 \\
\hline 1 件 分 析 時 間 & 20 分 & $\begin{array}{lll}3 & 0 & \text { 分 }\end{array}$ & 50 分 & 180 分 & 60 分 & 40 分 \\
\hline 1 人 8 時間 処理件数 & 40 件 & $\begin{array}{lll}3 & 0 & \text { 件 }\end{array}$ & 40 件 & 20 件 & 35 件 & 50 件 \\
\hline 1 件 分 析費 用 & 30 円 & 35 円 & 55 円 & 20 月 & 10 円 & 10 円 \\
\hline 作 業 環 & 良 & 良 & 良 & 不良 & 良 & 稍々不良 \\
\hline 不 適 用 鋼 種 & Mo & な & 合金銅 & な & な & な \\
\hline
\end{tabular}

* 集中法螢光 $\mathrm{X}$ 線分析装置を大同平井工場て睛入し，34年5月より鉛分析を实施している. 
もし分離した場合は分離鉛の定量の方法を如何 にするかにわけられる，鉄こ共存のまま鉛を定 量するポーラログラフ法および比色法は不適用 鋼種，精度，分析能率等に若干欠点があり工場 分析として不適当と判断し，鉛を大部分の鉄か ら簡単に分離する方法を検討した。

JIS 法（硫化水素分離一モリブデン酸鉛重量 法)硫化水素分離潐練を要し，作業能率を著 しく低下するので，新に硫酸分離法を採用し第 1 表の如く作業能率，環境等を改善し得た。さ らに硫裂分離した鉛を EDTA 容量法によって 定量するととによって作業能率を高め，筆者等 の所期の目的である鉛分析の迅速性の向上をは ぽ達したので，との分析法について報告する。

\section{II 分析方 法}

\section{1. 試 薬}

硫酸溶液 $\mathrm{H}_{2} \mathrm{SO}_{4}(1+4)$

熱塩酸溶液 $\mathrm{HCl}(1+1)$

塩酸ヒドロキシルアミン溶液：

$$
100^{\circ} \mathrm{NH}_{2} \mathrm{OH} \cdot \mathrm{HCl}
$$

ロッセル塩溶液 : $400_{0} \mathrm{KNaC}_{t} \mathrm{H}_{4} \mathrm{O}_{8} ・ 4 \mathrm{H}_{2} \mathrm{O}$ 楥衝液 $(\mathrm{PH} 10): \mathrm{NH}_{\downarrow} \mathrm{Cl} 70 \mathrm{~g}, \mathrm{NH}_{4} \mathrm{OH} 570 \mathrm{ml}$

を水で 11 とする.

シアン化カリ溶夜 : $20 \% \mathrm{KCN}$

苛性ソーダ溶液 : $24 \% \mathrm{NaOH}$

指示薬：エリオクローム・ブラック $0.5 \mathrm{~g}$,

$\mathrm{NH}_{2} \mathrm{OH} ・ \mathrm{HCl} 5 \mathrm{~g}$ をアルコールに溶解し

て $100 \mathrm{ml}$ とし, 褐色㼛に保存する。

EDTA溶液：最純 EDTA1.7967g を水に浴

解して正しく 11 とする。

水: 蒸溜水

\section{2. 分析操作}

試料 $5 \mathrm{~g}$ を $250 \mathrm{ml}$ 三角フラスフに正しく科 り取り, 硫酸溶液 $130 \mathrm{ml}$ を加气，静加加熱 分解する，反応が終れば $20^{\circ} \mathrm{C}$ 以下に冷却し， No.5 b沪紙で沪過する．フランスコおよび沪紙 約 $50 \mathrm{ml}$ の水で洗浄する.

ロートを元のフラスコ上におき，熱堤酸溶液 $5 \mathrm{ml}$ で 2 回, 熱水で 3 回残渣 および沪紙を洗 j.

洗液に塩酸ヒドロキシルアミン溶液 $1 \mathrm{ml}$,
ロッセル 塩溶液 $5 \mathrm{ml}$, 緩衝液 $10 \mathrm{ml}$ さらにシ アン化カリ溶澉 $5 \mathrm{ml}$ を加えてよくふりまぜる。 鉄等が完全にいんぺいされたのち, 苛性ソーダ 溶液 $10 \mathrm{ml}$, 指示楽 $2 \sim 3$ 滴を加光 EDTA 溶 液で滴定し、青紫色より青色に変化したところ を終点とする。

$$
\mathrm{Pb}_{0}^{\circ}=(\mathrm{A}-\mathrm{B}) \times 0.020
$$

$\mathrm{A}=$ 実際試料に要した EDTA 溶液使用量 $(\mathrm{ml})$ $\mathrm{B}=$ 空実験に要した EDTA 溶液使用量 $(\mathrm{ml})$

\section{III 基 礎 実 験}

緒言で述べた如く， $\mathrm{Pb}$ を大部分の $\mathrm{Fe}$ から 分離する硫酸分離法および EDTAによる分離 の鉛定量法の 2 項目について, その諸条件を検 討した。

1 硫酸溶液による $\mathrm{Pb}$ の分離について 硫酸溶液のみを使用して多量の $\mathrm{Fe}$ 加 $\mathrm{Pb}$ を 分離す場合には，沈澱した $\mathrm{PbSO}_{\star}$ が若干水溶 性のため, 種々の分離条件が問題となるのでそ れらについて実験を行った。

\section{1-1 硫酸濃度との関係}

鉛快削鋼 $\mathrm{S} 50 \mathrm{CF}(\mathrm{Pb}=0.180 \pm 0.002 \%) 5 \mathrm{~g}$ を 秤取し、 $\mathrm{H}_{2} \mathrm{SO}_{4}$ 濃度を $(1+2)$ 汃ら $(1+16)$ まで数種に変えた溶液約 $200 \mathrm{ml}$ に溶解し，試 料分解後 $15^{\circ} \mathrm{C}$ 亿冷却する. 沪紙 No. $5 \mathrm{c}$ で沪 過し, 残渣を $\mathrm{HNO}_{\mathrm{s}}(1+1)$ 亿容解し, 以下 J I S法に準じて $\mathrm{Pb}$ を $\mathrm{PbMoO}_{4}$ として科量 する。第 1 図が得られた $\mathrm{Pb} 。$ よ $\mathrm{H}_{2} \mathrm{SO}_{+}$濃度 との関係である。

$\mathrm{H}_{2} \mathrm{SO}_{4}$ が濃いほど試料分解速度がはやく（た だし $1+2$ の場合はおそい)，淡いはど沪過速度

第 1 図 $\mathrm{Pb}$ と $\mathrm{H}_{2} \mathrm{SO}_{4}$ 濃度との関係

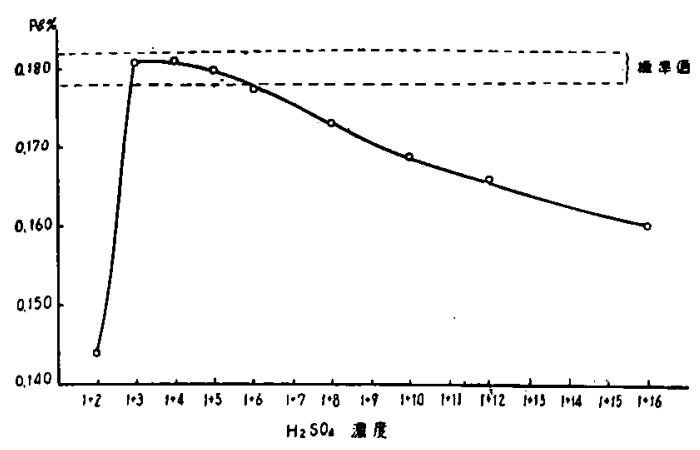


がはやい．実験の結果 $(1+3) \sim(1+5) の$ 浱度て 標準值が得られた．以後の実験は $\mathrm{H}_{2} \mathrm{SO}_{4}(1+4)$ を使用した。

\section{1-2 液温との関係}

武料を分解後沪過する時 $\mathrm{PbSO}_{1}$ は酸に若干 溶解し，この多少は液温に関係すると考えられ るので検討を行った. S50CF $5 \mathrm{~g}$ を $\mathrm{H}_{2} \mathrm{SO}_{4}(1+$ 4) 約 $200 \mathrm{ml}$ で溶解し, 沪過時の液温を $8^{\circ} \sim 70^{\circ} \mathrm{C}$ まで変え，前項と同一操作で $\mathrm{Pb}$ を定量した。

第 2 図は $\mathrm{Pb} \%$ と液温との関係である，Pboは

第 2 図 $\mathrm{Pb}$ と液温との関係

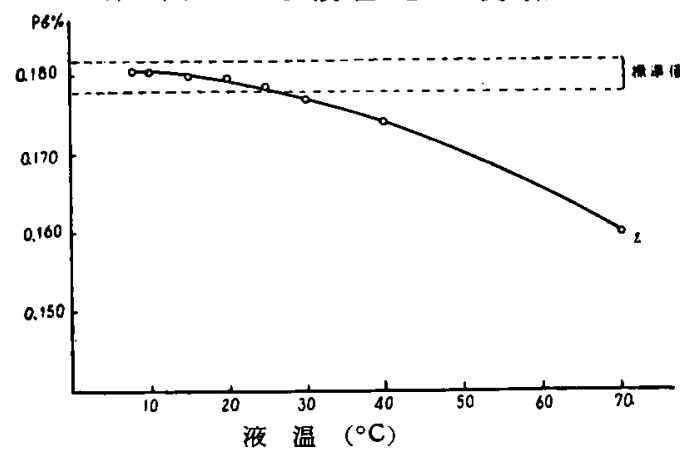

温度に比例して 低值を示す。 $30^{\circ} \mathrm{C}$ 以下で $\mathrm{Pb}$ の標準值に対し， $0.002 \%$ 以内で定量できるの で，安全を考えて $20^{\circ} \mathrm{C}$ 以下とした。

\section{1-3 洗净液および洗浄回数}

沪過後の洗浄液の種類, 洗浄回数は $\mathrm{PbSO}_{4}$ の収率わよび $\mathrm{Pb}$ 以外の残渣量に関係する。

試料 $5 \mathrm{~g}$ を $\mathrm{H}_{2} \mathrm{SO}_{4}(1+4) 200 \mathrm{ml}$ 亿溶解し, $20^{\circ} \mathrm{C}$ に冷却して沪過する， $\mathrm{H}_{2} \mathrm{SO}_{4}(1+4)$ ，(1 +16）および $\mathrm{H}_{2} \mathrm{O}$ でそれぞれ，10回洗浄し残 渣中の $\mathrm{Pb}$ を定量した。との際一回の洗浄液量 は約 $20 \mathrm{ml}$ である。

第 2 表 洗浄液および洗浄回数

\begin{tabular}{|c|c|c|c|}
\hline 試 料 & 洗 净 液 & 洗浄回数 & $\mathrm{Pb}^{\circ} 0$ \\
\hline \multirow{6}{*}{ S50CF } & \multirow{2}{*}{$\mathrm{H}_{2} \mathrm{SO}_{4}(1+4)$} & 3 & 0.184 \\
\hline & & 10 & 0.180 \\
\hline & \multirow{2}{*}{$\mathrm{H}_{2} \mathrm{SO}_{4}(1+16)$} & 3 & 0.183 \\
\hline & & 10 & 0.170 \\
\hline & \multirow{2}{*}{$\mathrm{H}_{2} \mathrm{O}$} & 3 & 0.184 \\
\hline & & 10 & 0.178 \\
\hline
\end{tabular}

第 2 表の如く洗浄回数 3 回の場合はいずれの 洗浄液でも結果にほとんど差がない.10回のと きはいずれる 3 回に比較して若干低值を示して いる. また残渣中に残存する $\mathrm{Fe}$ 量は 1 ～ 2 回 の洗浄で，それ以上行っても $\mathrm{Fe}$ 量が減少しな かったため水約 $50 \mathrm{ml} て ゙$ 洗浄するのがよい。

1-4 沪紙の選択

てれまでの実験はすべて 東洋沪紙 No. 5c を 使ったが，沪過速度がおそいため No.5b（パ ルプ有無）を検討した。

第 3表 沪 紙 0 選 択

\begin{tabular}{|l|c|c|c|}
\hline 試 料 & $\mathrm{No.5b}+$ パルプ & $\mathrm{Pb} \%$ & 平均 $\mathrm{Pb} \%$ \\
\hline & & 0.182 & \\
& 有 & 0.184 & 0.182 \\
& & 0.179 & \\
\cline { 2 - 4 } $\mathrm{S} 50 \mathrm{CF}$ & & 0.182 & \\
& & 0.181 & 0.183 \\
& 無 & 0.186 & \\
\hline
\end{tabular}

第 3 表の如くNo.5bを使った場合，パルプの 有無にかかわらずNo.5c と同一結果が得られ沪 過速度もはやい，なおNo.5aは多少 $\mathrm{PbSO}_{4}$ が通 過して低值を出すため不適である，従ってNo． 5b 沪紙のみで沪過を行うのが最適である。

1-5 分解酸の液量および放置時間 沪過時間をできるだけ縮少するため分解酸の 液量を検討した。すなわち武料 $5 \mathrm{~g}^{\text {を }} \mathrm{H}_{2} \mathrm{SO}_{4}(1$ +4) $100,120,140,160,180 \mathrm{ml}$ 江溶解し $15^{\circ} \mathrm{C}$ 以下に冷却した場合， $100 \mathrm{ml} て ゙$ 溶解したものの みが $\mathrm{FeSO}_{4}$ の結晶を析出した。 また $120 \mathrm{ml}$ は激しく撹䢁することによって，塩の析出をみ とめたので以後 $130 \mathrm{ml}$ 使用することにした。

また多量の試料を同時に分析する場合には， 試料溶解後沪過までの放置時間に差ができるた め, これについても検討を加えたが定量值に差 はなかった。

1-6 $\mathrm{H}_{2} \mathrm{O}_{2}$ による黒色残渣の分解

$\mathrm{H}_{2} \mathrm{SO}_{4}$ のみで試料を分解するときは相当量 の黒色残渣ができててのなかに $\mathrm{Pb}$ 以外の元素 が多く含まれている. 分傩された $\mathrm{Pb}$ 重量法, 容量法いずれの方法によって定量する場合も， 共存元素はできるだけ少量であることが望ま 
しい.

黒色残渣を少くするため $\mathrm{H}_{2} \mathrm{SO}_{4}(1+4)$ 亿溶 解後 $\mathrm{H}_{2} \mathrm{O}_{2}$ 処理を行い，残查をできるだけ少く してから $\mathrm{Pb}$ を定量したのが第4 表である。

第 4 表 $\mathrm{H}_{2} \mathrm{O}_{2}$ に上る黒色残渣の分解

\begin{tabular}{|c|c|c|c|c|}
\hline 試＼cjkstart料 & $\begin{array}{c}15 \% \\
\mathrm{H}_{2} \mathrm{O}_{2} \\
\end{array}$ & $\mathrm{~Pb} \%$ & 平均 $\mathrm{Pb} \%$ & $\mathbf{R}$ \\
\hline \multirow{3}{*}{ S50CF } & & 0.186 & \multirow{3}{*}{0.181} & \multirow{3}{*}{0.011} \\
\hline & 10 & 0.175 & & \\
\hline & & 0.182 & & \\
\hline \multirow{6}{*}{$\begin{array}{l}\mathrm{SCM} 22 \mathrm{~F} \\
\mathrm{~Pb}=0.165 \%\end{array}$} & & 0.167 & \multirow{3}{*}{0.166} & \multirow{3}{*}{0.003} \\
\hline & 0 & 0.165 & & \\
\hline & & 0.168 & & \\
\hline & \multirow{3}{*}{10} & 0.140 & \multirow{3}{*}{0.140} & \multirow{3}{*}{0.009} \\
\hline & & 0.144 & & \\
\hline & & 0.135 & & \\
\hline
\end{tabular}

$\mathrm{H}_{2} \mathrm{O}_{2}$ 処理を行わない場合は残查中に $\mathrm{Fe}$ が 10〜30mg 程度残るが，処理を行えば殆んど共 存しててない. しかし $\mathrm{Pb} \%$ は $\mathrm{H}_{2} \mathrm{O}_{2}$ の処理に よって SCM 22F (Cr-Mo鋼) は低值を示し, S50C F と共に若干バラッキが大きい．このた め, $\mathrm{H}_{2} \mathrm{O}_{2}$ 処理を行わないのが適当之考えら れる。

以上 1-1ないし1-6の基礎実験により $\mathrm{Pb}$ を大
部分の鉄から分離する諸条件として， $\mathrm{H}_{2} \mathrm{SO}_{4}$ $(1+4) 130 \mathrm{ml}$ で武料を分解し， $20^{\circ} \mathrm{C}$ 以下に冷 却し，No. $5 b$ 沪紙で沪過後水 $50 \mathrm{ml}$ で洗浄する ことを決めた。

\section{EDTA法による $\mathrm{Pb}$ の定量について}

前項に述べた如く大部分の $\mathrm{Fe}$ から分離され た $\mathrm{Pb}$ は J I S法に準じて $\mathrm{PbMoO}_{4}$ として重 量法9）により定量し，満足な絬果が得られたが， さらに分析の迅速化に EDTA 法 ${ }^{10)}$ を応用する ための諸条件を検討した。

\section{2-1 残渣溶解}

試料を $\mathrm{H}_{22} \mathrm{SO}_{4}$ に溶解後，沪過した残渣中の $\mathrm{Pb}$ は金属 $\mathrm{Pb}$ と $\mathrm{Pb}$ 塩の状態で存在している模 様である．J I S法の如く $\mathrm{HNO}_{3}(1+1)$ で残 渣を処理した時には $\mathrm{Pb}$ は定量的に溶液になる が，同時に黒色残渣中の他の金属もほこんど溶 液となる，熱 $\mathrm{HCl}(1+1) 5 \mathrm{ml}$ で 2 回，熱水で 3 回沪紙上から洗浄したときの溶液は， $\mathrm{HNO}_{3}$ 処 理に比較して 共存元素が少量である．S50C

(炭素鎆)，S K 4 (高炭素鎆)，S CM 3 ( $\mathrm{Cr}-$ Mo鋼）S U J 2 (軸受鋼)， S U S 2 (クロム ステンレス鋼) の鉛快削鋼 $5 \mathrm{~g}$ を $\mathrm{H}_{2} \mathrm{SO}_{4}$ 溶解後,

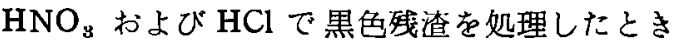

第 5 表 残渣処理による共存元素の量

\begin{tabular}{|c|c|c|c|c|c|c|c|c|c|c|c|c|c|c|}
\hline \multicolumn{2}{|l|}{ 試 料 } & C & $\mathrm{Si}$ & $\mathbf{M n}$ & $P$ & $\mathbf{s}$ & $\mathrm{Cu}$ & $\mathrm{Ni}$ & $\mathrm{Cr}$ & Mo & $\mathrm{Pb}$ & $\mathrm{Al}$ & $\mathrm{Ti}$ & $\mathrm{Fe}$ \\
\hline \multirow{3}{*}{ S52.C } & 組 成 \% & 0.53 & 0.38 & 0.69 & 0.022 & 0.018 & 0.24 & 0.10 & 0.14 & 0.04 & 0.19 & 0.02 & $<0.01$ & - \\
\hline & $\begin{array}{l}\mathrm{HNO}_{3} \\
\text { 処理 } \mathrm{mg}\end{array}$ & - & 0.8 & 1.3 & - & - & 10.0 & 0.1 & $\operatorname{tr}$ & 0.4 & 9.5 & - & - & 26.6 \\
\hline & $\begin{array}{l}\mathrm{HCl} \\
\text { 処理mg }\end{array}$ & - & - & 0.1 & - & - & 2.8 & 0.1 & 0.1 & 0.1 & 9.5 & $\operatorname{tr}$ & $\mathrm{tr}$ & 13.1 \\
\hline \multirow{2}{*}{ SK4 } & 組成 \% & 1.02 & 0.25 & 0.38 & 0.009 & 0.006 & 0.18 & 0.09 & 0.08 & 0.03 & 0.13 & 0.02 & $<0.01^{1}$ & - \\
\hline & $\begin{array}{l}\mathrm{HC} \\
\text { 処理mg }\end{array}$ & - & - & $\operatorname{tr}$ & - & - & 2.9 & 0.1 & $\operatorname{tr}$ & 0.1 & 6.5 & $\operatorname{tr}$ & $\operatorname{tr}$ & 9.8 \\
\hline \multirow{3}{*}{ SCM3 } & 組 成 \% & 0.36 & 0.23 & 0.76 & 0.020 & 0.008 & 0.25 & 0.10 & 1.08 & 0.23 & 0.15 & 0.05 & $<0.01$ & - \\
\hline & $\begin{array}{l}\mathrm{HNO}_{3} \\
\text { 処理mg }\end{array}$ & - & 0.3 & $\operatorname{tr}$ & - & - & 8.5 & 0.2 & $\operatorname{tr}$ & 1.9 & 7.5 & - & - & 9.0 \\
\hline & $\begin{array}{l}\mathrm{HCl} \\
\text { 処理 } \mathrm{mg}\end{array}$ & - & - & $\operatorname{tr}$ & - & - & 3.8 & 0.2 & 0.1 & 0.7 & 7.5 & $\operatorname{tr}$ & $\operatorname{tr}$ & 9.1 \\
\hline \multirow{2}{*}{ SUJ2 } & 組成 \% & 0.98 & 0.26 & 0.36 & 0.017 & 0.008 & 0.10 & 0.05 & 1.33 & 0.03 & 0.15 & 0.02 & $<0.01^{1}$ & - \\
\hline & 処理mg & - & - & $\operatorname{tr}$ & - & - & 1.3 & 0.1 & 0.1 & 0.1 & 7.5 & $\operatorname{tr}$ & $\operatorname{tr}$ & 6.3 \\
\hline \multirow{2}{*}{ SUS2 } & 組 成 \% & 0.15 & 0.49 & 0.72 & 0.030 & 0.007 & 0.16 & 0.24 & 12.68 & 0.08 & 0.11 & 0.03 & $<0.01^{\prime}$ & - \\
\hline & $\begin{array}{l}\mathrm{HC} 1 \\
\text { 処理mg }\end{array}$ & - & - & $\operatorname{tr}$ & - & - & 2.3 & 0.3 & 0.3 & 0.4 & 5.5 & $\operatorname{tr}$ & tr & 11.0 \\
\hline
\end{tabular}


の $\mathrm{Pb}$ と共存する元素を定量したのが第 5 表で ある. 残渣溶液中の各元素の定量法は

$\mathrm{Si} ：$ ケィリブデン酸吸光々度法

Mn : 過 $コ$ ド酸吸光々度法

$\mathrm{Cu}$ : ネオクユプロイン吸光々度法

$\mathrm{Ni}$ ：ヂメチルグリオキシム财光々度法

$\mathrm{Cr}$ ：ヂフエニルカルバジッド吸光々度法

Mo：硫シアンソーダー塩化第一錫吸光々度 法

$\mathrm{Fe}$ ：スルホサリチル酸吸光々度法

$\mathrm{Al}$ : アルミノン昅光々度法

$\mathrm{Ti}$ ：スルホサリチル酸吸光々度法 である。

分離された鉛は $\mathrm{HNO}_{3}$ でも $\mathrm{HCl}$ でも定量 的に溶解し，共存元素は $\mathrm{HCl}$ の方が少いため 残渣溶解法しして熱 $\mathrm{HCl}(1+1) 5 \mathrm{ml}$ で 2 回, 熱湯で 3 回沪紙上より注いで行った。

\section{2-2 EDTA 滴定の条件}

鉛溶液のみを EDTAで滴定する場合はエリ オクロームブラックTを指示楽として $\mathrm{pH} 10$ て 满足な結果が得られる。しかし第 5 表の如く $\mathrm{Pb}$ に共存する元素があるため KC N によるい んべいを行った。この際溶液中に若干存在す $\mathrm{Fe}^{+++} \mathrm{Fe}^{++}$に還元し, いんぺい完全にす るため $\mathrm{NH}_{2} \mathrm{OH} ・ \mathrm{HCl}$ を使用する。また $\mathrm{KCN}$ のいんぺいは中性で最も有効に働くため酸度の 調整が必要である。 さらにアルカリ性で $\mathrm{Pb}$ 等 の沈澱を防ぐため，ロッセル塩で錯塩としたの ち，中性まで酸度を調整する必要がある。

これらの条件を満し，さらに $\mathrm{pH} 10$ 前後で滴 定するために加える試桨の濃度, 添加量および 温度か問題となる。

(1) $\mathrm{pH}$ の調節

$\mathrm{Pb}$ 標準液 $10 \mathrm{ml}(1 \mathrm{ml}=1 \mathrm{mgPb})$ を分取し, $\mathrm{HCl}(1+1) 10 \mathrm{ml}, 10 \% \mathrm{NH}_{2} \mathrm{OH} \cdot \mathrm{HCl}$ 溶液 1 $\mathrm{ml}, 40 \%$ 口,セル塩溶液 $5 \mathrm{ml}, \mathrm{pH} 10$ の緩衝液 10 $\mathrm{ml}$ を加えたとき溶液の $\mathrm{pH}$ は 8 前後となり， K C Nのいんぺいにはちょうど適当な酸度とな る. 元に20\% K C N溶液 $5 \mathrm{ml}$ を加えて Fe, $\mathrm{Cu}$ 等をいんべいする，さらに NaOHによって pH10 前後とするため, その濃度および量を第 6 表のように変えてみた。
第 6 表 $\mathrm{pH}$ の調 節

\begin{tabular}{|c|c|c|c|c|c|}
\hline $\begin{array}{l}\mathrm{Pb} \\
\mathrm{mg}\end{array}$ & $\begin{array}{c}24 \% \\
\mathrm{NaOH} \\
\mathrm{ml}\end{array}$ & $\mathrm{pH}$ & $\begin{array}{c}\text { EDTA } \\
\mathrm{ml}\end{array}$ & $\begin{array}{c}\text { 検 }{ }^{\text {出 }} \\
\mathrm{Pb} \\
\mathrm{mg}\end{array}$ & 備 考 \\
\hline \multirow{4}{*}{$\cdot$} & 0 & 8.30 & $9.9 \widetilde{10.1}$ & - & $\begin{array}{l}\text { 笗点見 } \\
\text { にくい }\end{array}$ \\
\hline & 2.0 & 8.75 & 9.90 & 9.60 & " \\
\hline & 4.0 & 9.00 & 9.95 & 9.65 & - \\
\hline & 6.0 & 9.25 & 10.00 & 9.70 & - \\
\hline \multirow{6}{*}{10} & 8.0 & 9.50 & 10.15 & 9.85 & $\begin{array}{l}\text { 終点見 } \\
\text { や多 }\end{array}$ \\
\hline & 10.0 & 9.85 & 10.30 & 10.00 & " \\
\hline & 11.0 & 10.20 & 10.30 & 10.00 & " \\
\hline & 11.5 & 10.40 & $\begin{array}{r}10.3 \widetilde{10.5} \\
\end{array}$ & - & 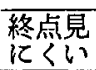 \\
\hline & 12.0 & 10.70 & - & - & 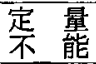 \\
\hline & 12.5 & 11.50 & - & - & " \\
\hline 0 & 10.0 & 9.90 & 0.30 & 0 & - \\
\hline
\end{tabular}

$240_{0}^{\circ} \mathrm{NaOH}$ 浴液 $8 \sim 11 \mathrm{ml}$ で $\mathrm{Pb}$ で定量的に 反応し，満足な結果を得たので $10 \mathrm{ml}$ の使用を 定めた。

以上の操作で滴定終点が見にくい場合は，多 分 $\mathrm{pH}$ が9.5 10.2 の範囲にないためである. このときはさらに緩衝液を迫加することによっ て簡単に定量可能となる。

(2) 滴定時の液温

$\mathrm{Pb}$ 標準溶液 $10 \mathrm{mg}$ をとり前記の如く操作し， $\mathrm{pH}$ を10に調節し，液温を $20^{\circ} \sim 70^{\circ} \mathrm{C}$ 亿変え， EDTA 滴定を行った結果が第 7 表である.

$20^{\circ} \mathrm{C}$ では反応がおそく滴定液を入れすぎる 恐れがあり， $30^{\circ} \sim 50^{\circ} \mathrm{C}$ が適温である。

\section{2-3 共存元素の影響}

第 7 表 滴定時の液温

\begin{tabular}{|c|c|c|c|c|}
\hline $\begin{array}{l}\mathrm{Pb} \\
\mathrm{mg}\end{array}$ & 液 ${ }^{\circ} \mathrm{C}$ & $\begin{array}{c}\text { EDTA } \\
\mathrm{ml}\end{array}$ & $\begin{array}{ll}\text { 検 } & \text { 出 } \\
\mathrm{Pb} & \mathrm{mg}\end{array}$ & 考 \\
\hline \multirow{6}{*}{10} & 20 & 10.60 & 10.30 & 反応おそし \\
\hline & 30 & 10.30 & 10.00 & 䅂点見やすい \\
\hline & 40 & 10.30 & 10.00 & " \\
\hline & 50 & 10.30 & 10.00 & " \\
\hline & 60 & 10.20 & 9.90 & 終点見にくい \\
\hline & 70 & - & - & " \\
\hline 0 & 40 & 0.30 & 0 & - \\
\hline
\end{tabular}


昭和34年11月 (1959)了

第 5 表に示した滴定溶液中に存在する $\mathrm{Pb}$ 以 外の金属はほとんど EDTA と錯塩をつくり， $\mathrm{Pb}$ 分析值を高く出し，終点を見にくくするの で，前述の如く200\% K N 溶液 $5 \mathrm{ml}$ を加えて これらをいんぺいした．鋼中に存在して $\mathrm{Pb}$ 分 析に影響すると考えられる各元素につき200る KCN $5 \mathrm{ml}$ でどの程度いんぺいできるか検討 行った。

(1) $\mathrm{Fe}$

純鉄 $1 \mathrm{~g}$ を $\mathrm{HCl}(1+1)$ に溶解し，水で正しく $100 \mathrm{ml}$ とする．乙の標準液に $\mathrm{Pb}$ 標準液を加え 前述の操作で定量を行ったのが第 8-1表であ る． $\mathrm{Fe}$ が単独に $120 \mathrm{mg}$ 以上共存する場合は滴 定不能であるが，一般には15mg 以下であるた め妨害はない．また液温 $30^{\circ} \mathrm{C}$ 以上であればい んぺい時間は 3 分程度である。

第 8-1 表 $\mathrm{Fe} の$ 影锌

\begin{tabular}{|c|c|c|c|c|}
\hline $\begin{array}{l}\mathrm{Pb} \\
\mathrm{mg}\end{array}$ & $\begin{array}{l}\mathrm{Fe} \\
\mathrm{mg}\end{array}$ & $\begin{array}{c}\text { EDTA } \\
\text { ml }\end{array}$ & $\left|\begin{array}{c}\text { 梚出 } \mathrm{Pb} \\
\mathrm{mg}\end{array}\right|$ & 蒯 \\
\hline 0 & 0 & 0.40 & 0 & \\
\hline \multirow{5}{*}{10} & 30 & 0.40 & 10.00 & \\
\hline & 50 & 1040 & 10.05 & \\
\hline & 70 & 10.45 & 10.05 & \\
\hline & 120 & 10.40 & 10.00 & \\
\hline & 140 & - & - & 滴定不能 \\
\hline
\end{tabular}

第 8-2 表 $\mathrm{Cu}, \mathrm{Ni}$ の影殒

\begin{tabular}{|c|c|c|c|c|}
\hline $\begin{array}{l}\mathrm{Pb} \\
\mathrm{mg}\end{array}$ & $\begin{array}{l}\mathrm{Cu} \\
\mathrm{mg}\end{array}$ & $\begin{array}{c}\mathrm{Ni} \\
\mathrm{mg}\end{array}$ & $\begin{array}{c}\text { EDTA } \\
\text { mg }\end{array}$ & 検 $\begin{array}{c}\text { 出 } \\
\text { bmg }\end{array}$ \\
\hline 0 & 0 & 0 & 0.35 & 0 \\
\hline \multirow{2}{*}{10} & 20 & 0 & 10.40 & 10.10 \\
\hline & 0 & 200 & 10.30 & 9.95 \\
\hline
\end{tabular}

(2) $\mathrm{Cu}, \mathrm{Ni}$

$\mathrm{Cu} ， \mathrm{Ni}$ の標準溶液を使用した結果が第 8一 2表である，Cu，NiはＫＣＮと常温で錯塩をつ くり十分いんペいされる。

鋼中の $\mathrm{Cu}$ は，その全部が溶液にきても約20 $\mathrm{mg}$ 程度であるのでそれ以上は問題とならない． また Ni は第 5 表より明瞭なでとく $1 \mathrm{mg}$ 以下で 定量の支障とならない.

(3) $\mathrm{Cr}$

$\mathrm{Cr}$ の標準液を $\mathrm{Pb}$ 液に加え前述の操作によっ
て $\mathrm{Pb}$ を定量した結果が第 8-3 表である. Cr 2mg 以上を含む場合は低值となり，その量 の増加とともに差は大きくなる，6mg以上の共 存は滴定不能となる。しかし第 5 表からみて Cr の共存は $1 \mathrm{mg}$ 以下のため一般に支障はない.

(4) $\mathrm{Mn}$

$\mathrm{Pb}$ 標準液に Mn 標潗液を加え. 前述の操 作にしたがいその影響をしらべた，第 8一4表 は滴定温度を変えたときの $\mathrm{Pb}$ 量で, 温度に比 例して高值を出し，Mnの影響が誌められた。

第 8-3 表 $\operatorname{Cr} の$ 影㗽

\begin{tabular}{|c|c|c|c|c|c|}
\hline $\begin{array}{l}\mathrm{Pb} \\
\mathrm{mg}\end{array}$ & $\mathrm{Cr}_{\mathrm{r}}$ & $\mathrm{mg} \mid$ & $\begin{array}{c}\text { EDTA } \\
\mathrm{ml}\end{array}$ & $\begin{array}{l}\text { 出 } \\
\text { Pb mg }\end{array}$ & 考 \\
\hline 0 & & 0 & 0.45 & 0 & - \\
\hline \multirow{6}{*}{10} & & 1 & 10.50 & 10.10 & - \\
\hline & & 2 & 10.35 & 9.90 & - \\
\hline & & 3 & 10.20 & 9.75 & - \\
\hline & & 4 & 10.00 & 9.55 & - \\
\hline & & 6 & - & 一 & 終点見にくい \\
\hline & & 8 & - & - & 滴定不能 \\
\hline
\end{tabular}

第 8-4 表 $\mathrm{Mn}$ の影響（液温）

\begin{tabular}{|c|c|c|c|c|c|}
\hline $\begin{array}{l}\mathrm{Pb} \\
\mathrm{mg}\end{array}$ & $\begin{array}{l}\mathrm{Mn} \\
\mathrm{mg}\end{array}$ & ${ }^{\circ}{ }^{\circ} \mathrm{C}^{\text {温 }}$ & $\begin{array}{c}\text { EDTA } \\
\text { ml }\end{array}$ & $\begin{array}{c}\text { 検出 } \mathrm{Pb} \\
\mathrm{mg}\end{array}$ & 備 考 \\
\hline \multirow{5}{*}{10} & 0.28 & 20 & 10.50 & 10.00 & - \\
\hline & " & 30 & 10.60 & 10.10 & - \\
\hline & " & 40 & 10.70 & 10.20 & - \\
\hline & " & 50 & 11.15 & 10.65 & - \\
\hline & " & 60 & 11.40 & 10.90 & - \\
\hline 0 & 0 & 40 & 0.50 & 0 & - \\
\hline
\end{tabular}

第 8-5 表 $\mathrm{Mn}$ の影鄉

\begin{tabular}{|c|c|c|c|c|c|}
\hline $\begin{array}{l}\mathrm{Pb} \\
\mathrm{mg}\end{array}$ & $\begin{array}{l}\mathrm{Mn} \\
\mathrm{mg}\end{array}$ & 液温 ${ }^{\circ} \mathrm{C}$ & $\begin{array}{c}\text { EDTA } \\
\mathrm{ml}\end{array}$ & $\left|\begin{array}{c}\text { 検出 } \mathrm{Pb} \\
\mathrm{mg}\end{array}\right|$ & 请 考 \\
\hline 0 & 0 & 40 & 0.50 & 0 & - \\
\hline \multirow{5}{*}{10} & 0.14 & " & 10.65 & 10.15 & - \\
\hline & 0.28 & " & 10.70 & 10.20 & - \\
\hline & 0.56 & " & 11.00 & 10.50 & - \\
\hline & 1.12 & " & $\begin{array}{r}11.5 \widetilde{12.0} \\
\end{array}$ & 一 & $\begin{array}{l}\text { 終点見 } \\
\text { 亿会 }\end{array}$ \\
\hline & 1.68 & " & $\begin{array}{r}11.3 \sim \\
12.5\end{array}$ & - & " \\
\hline
\end{tabular}


また Mn 量による影響は第8一5 表で正の誤 差を生じ, 1mg以上では終点がみにくい，実際 試料では $\mathrm{Mn}$ の共存量は $0.1 \mathrm{mg}$ 以下のため, 滴 定誤差内に入り，Pb。にほこんど妨害ない.

(5) Al, Ti

$\mathrm{Al}$ および $\mathrm{Ti}$ の標準液を使用して前述の様 に実験した結果が第 8ー6表である.

第 8-6 表 A1, Ti の影響

\begin{tabular}{|c|c|c|c|c|}
\hline $\begin{array}{r}\mathrm{Pb} \\
\mathrm{mg}\end{array}$ & Al $\mathrm{mg}$ & $\begin{array}{l}\mathrm{Ti} \\
\mathrm{mg}\end{array}$ & $\begin{array}{c}\text { EDTA } \\
\text { ml }\end{array}$ & $\begin{array}{c}\text { 梚出 } \mathrm{Pb} \\
\mathrm{mg}\end{array}$ \\
\hline 0 & 0 & 0 & 0.40 & 0 \\
\hline \multirow{6}{*}{10} & 0.5 & 0 & 10.50 & 10.10 \\
\hline & 1.0 & 0 & 10.45 & 10.05 \\
\hline & 2.0 & 0 & 10.45 & 10.05 \\
\hline & 4.0 & 0 & - & - \\
\hline & 0 & 0.3 & 10.40 & 10.00 \\
\hline & 0 & 0.6 & - & - \\
\hline
\end{tabular}

Al 2mg, Ti $6 \mathrm{mg}$ の共存は終点不明である。 一般に銅中に存在する $\mathrm{Al}, \mathrm{Ti}$ は少量で $\mathrm{Pb}$ 溶 液中にくる量は $0.1 \mathrm{mg}$ 以下のにめ影響がない。

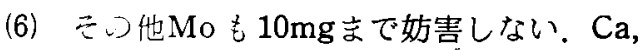
$\mathrm{Mg}$ は pH10で EDTA と定量的に反応するか， 鋼中には一般に存在しないため問題でない。む しう天然水からくる $\mathrm{Ca} ， \mathrm{Mg}$ に注意し, 蒸溜水 の使用か望まれる。

以上共存する主要な元素についてその影響を 検討したが，第 5 表より明瞭なでとく一般鋼種 にむいては項の分析方法で十分満足すべき結 果を得る。

各元素許容範囲を越える場合には，K C N量 苍増すか,トリエタノールアミン等により $\mathrm{Mn}$, Al のいんぺいを行うべきである.

\section{川分 析 結 果}

前項の基碟実験によってII項の分析方法を定 め,てれにより実際試料として S 50 C (炭素鋼), CSM 3 (Cr-Mo鋼)，SK 4 (高炭素鋼)，SUJ 2

(軸受鋼)，USS 2 (Crステンレス鎆）および N B S 130 (米国標準試料一炭素鋼) の鉛快削 鋼を分析した。第 9 表は各試料の分析結果で，
第 9 表 実際試料の分析結果

\begin{tabular}{|c|c|c|c|c|c|}
\hline 試料 名 & $\begin{array}{c}\mathrm{Pb} \\
\text { 標準值 } \\
\end{array}$ & $\mid \begin{array}{l}\text { 分析 } \\
\text { 者 }\end{array}$ & $\begin{array}{c}\mathrm{Pb} \\
\text { 実験值 }\end{array}$ & 平均值 & $\mathbf{R}$ \\
\hline \multirow{3}{*}{ S50CF } & \multirow{3}{*}{0.188} & A & $\begin{array}{l}0.188 \\
0.184 \\
0.189\end{array}$ & 0.187 & 0.005 \\
\hline & & B & $\begin{array}{l}0.190 \\
0.187 \\
0.188\end{array}$ & 0.188 & 0.003 \\
\hline & & C & $\begin{array}{l}0.184 \\
0.187 \\
0.186\end{array}$ & 0.186 & 0.003 \\
\hline \multirow{2}{*}{ SCM3F } & \multirow{2}{*}{0.151} & A & $\begin{array}{l}0.150 \\
0.154 \\
0.151\end{array}$ & 0.152 & 0.004 \\
\hline & & B & $\begin{array}{l}0.153 \\
0.155 \\
0.149\end{array}$ & 0.152 & 0.006 \\
\hline SK4F & 0.127 & A & $\begin{array}{l}0.128 \\
0.128 \\
0.133\end{array}$ & 0.130 & 0.005 \\
\hline SUJ2F & 0.150 & A & $\begin{array}{l}0.150 \\
0.146 \\
0.152\end{array}$ & 0.147 & 0.006 \\
\hline SUS2F & 0.111 & A & $\begin{array}{l}0.108 \\
0.108 \\
0.110\end{array}$ & 0.109 & 0.002 \\
\hline NBS130 & 0.204 & A & $\begin{array}{l}0.200 \\
0.206 \\
0.204\end{array}$ & 0.203 & 0.006 \\
\hline
\end{tabular}

第10表 分 析 時 間

\begin{tabular}{|c|c|c|}
\hline 分析操作 & 1 件所要時間 & 50件所要時間 \\
\hline 科 量 & 1 & 50 \\
\hline 溶 & 5 & 45 \\
\hline 冷却 & 10 & 40 \\
\hline 沪過 & 10 & 45 \\
\hline 洗 & 3 & 25 \\
\hline 残渣 分 解 & 5 & 30 \\
\hline Whぺい & 4 & 30 \\
\hline $\mathrm{pH}$ 調節滴定 & 1 & 40 \\
\hline 計 & 39 & 305 \\
\hline
\end{tabular}

（以下508頁へ続く） 
鋼は熱処理によって硬化せず，冷間加工によってのみ 硬化する．焼鈷は通常 $1900 \sim 2000^{\circ} \mathrm{F}$ から水冷するか

第 1 図 Tenelon の冷間加工量と浅械的 性質との関係の一例

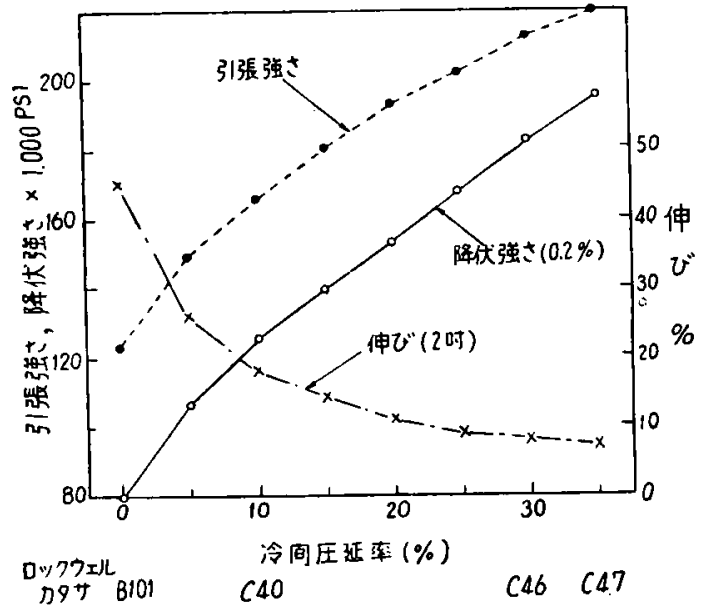

迅速に空冷される．参考のために冷間加工（圧延）の 影然および耐食性を示せば第 1 图および第 3 表の如く である.

第 3 表 Tenelon の耐食性の一例

\begin{tabular}{|c|c|c|}
\hline & 温 ${ }^{\circ} \mathrm{F}$ & $\begin{array}{l}\text { 浸清後 } 96 \mathrm{hr} \text { における1ケ月当 } \\
\text { の浸透深・ mil =1/1000 时 }\end{array}$ \\
\hline 5\%單酸 & 86 & 0.01 \\
\hline 10\%燐酸 & 86 & 0.01 \\
\hline $60^{\circ}$ 。醋酸 & 158 & 0.01 \\
\hline 50 硫酸 & 86 & 390 \\
\hline $55^{\circ}$ 硝酸 & 沸 鶝 & 0.07 \\
\hline $\begin{array}{l}\text { 他の鋼 } \\
\text { との比 } \\
\text { 䡈 }\end{array}$ & \multicolumn{2}{|c|}{$\begin{array}{l}\text { 弱酸に対しては301，302に匹敵し， } \\
\text { 強酸に対してはNi-bearing Grade } \\
\text { より少るが，430とはぼ同一である. }\end{array}$} \\
\hline
\end{tabular}

\section{（487頁より続く）}

S50CおよびS C M 3 については分析者恋変え て分析の正確度をしらぺた，正確度は標準值と よく一致し，精度も 3 個の実験值範囲が 0.003 〜 0.006\%で工業分析として良好と考えられる。

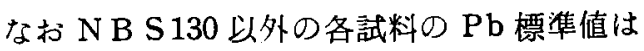
J I S 法により定めたものである.

第10表は分析所要時間の一例で，1件の場合 は約40分，50件を 1 名で分析する場合は 5 時間 程度である。

\section{$\mathrm{V}$ 結 言}

鉛快削銿中の鉛分析の迅速化を目的として分 析方法を種々検討した結果, 試料を硫酸のみに 分解し，鉛を大部分の鉄から分離したのち， E DTAによって定量する基礎条件军検討し，ほ 注满足すべき方法を確立した。

この方法に上れば,

（1）分析の正確度および精度は J I S 法に劣 らない.

（2）分析操作は简単で熟練を要せず，個人差 方少い。

(3) 1 試料の分析所要時間は約40分である.
（4） 50 試料は 1 名の分析者で約 5 時間で処理 できる。

（5） 1 試料の分析費用（人件費除く）は約 10 円である.

(6) 炭素鋼, 高炭素鋼, $\mathrm{Cr}-\mathrm{Mo}$ 鋼, 軸受鋼, $\mathrm{Cr}$ ステンレス鋼中の 0.02 0.4\%。の鉛を定 量できる。

終りに，本研究の実験に終始協力された小井 良三君に深謝いたします。

\section{文献}

1) 佐藤: 分析化学, 5 (1956) 304

2）神森, 池田：学振19委, (1958) 5179

3) G. H. Bush Analyst : 79 (1954) 697

4) E.B.Sande1: "Colonimetric Determination of Traces of Metals" Interscience (1953)

5) V. S. Meyer : Archiv für das Eisenhüt. 2 (1958) 677

6) Snell, et. al. : "Colorimetric Method of Analysis" Van Norstrand (1959)

7) JIS : G1229 (1957)

8) ASTM E30-561 24 (1956)

9) 足立, 小井：研究報告, No.534 (1959)

10）上野：“キレート滴定法”, 南江堂 (1956) 